\title{
APLIKASI KOMPOS TITONIA DAN JERAMI TERHADAP PENGURANGAN INPUT PUPUK BUATAN DAN PENGARUHNYA TERHADAP PRODUKSI PADI
}

\author{
Gusnidar $^{1}$, Syafrimen Yasin 1 , Burbey ${ }^{2}$, Resi Ezrari ${ }^{3}$ \\ Fakultas Pertanian U niversitas Andalas Padang \\ email: eni tanah@yahoo.co.id
}

\begin{abstract}
A research about "Application of Tithonia and rice straw compost on reduction of commercial fertilizer application and it effects on rice production" has been conducted in Sicincin, $2 \times 11$ Enam Lingkung, Padang Pariaman Region as well as in Soil Laboratory Agriculture Faculty, Andalas University, Padang. This research was conducted from January until May 2009. The objective of this research was to evaluate effect of titonia and rice straw compost application at intensification rice field on rice production and reduction of commencial fertilizer use. A field research was allocated based on Randomized Block Design with 6 treatments, those were: $A=$ Farmer Tradition Input ( $\left.200 \mathrm{~kg}^{\text {Urea ha }}{ }^{-1}+200 \mathrm{~kg} \mathrm{SP}^{-36} \mathrm{ha}^{-1}\right) ; B=R e c o m e n d e d ~ I n p u t ~(R=200$ kg Urea ha $\left.+100 \mathrm{~kg} \mathrm{SP}^{-1} 36 \mathrm{ha}^{-1}+75 \mathrm{~kg} \mathrm{KCl} \mathrm{ha}^{-1}\right)$; C= Application of Compost (5 ton rice straw ha' $\left.{ }^{-1}\right)+100 \%$ Recommendation Input (Urea + KCl + SP-36); D= Application of Compost (5 ton rice straw ha $\left.{ }^{-1}\right)+$ Urea $200 \mathrm{~kg} \mathrm{ha}^{-1}$, without $\mathrm{KCl}+$ P-starter $10 \mathrm{~kg} \mathrm{SP-36} \mathrm{ha-1}$; E= Application of Compost (Titonia 2,5 ton ha ${ }^{-1}+$ rice straw 2,5 ton ha' $\left.{ }^{-1}\right)+$ Urea $75 \%(R)(150 \mathrm{~kg}$ $\mathrm{ha}^{-1}$ ), withou KCl, and P-starter $10 \mathrm{~kg} \mathrm{SP-36} \mathrm{ha-1} ; \mathrm{F}=$ Application of Compost (Titonia 2,5 ton $\mathrm{ha}^{-1}+2,5$ rice straw ton ha' $\left.\mathrm{h}^{-1}\right)+$ Urea $50 \%(\mathrm{R})\left(100 \mathrm{~kg} \mathrm{ha}^{-1}\right)$, without KCl,and P-starter $10 \mathrm{~kg}$ SP-36 ha ${ }^{-1}$. Data from field research were statistically analysed. If the F-calculated was significantly different, they would be further analysed using LSD (5\%). The results showed that application of rice straw-titonia mix compost on intensification rice field could reduce commercial fertilizer by $50 \mathrm{~kg}$ Urea ha- ${ }^{-1}\left(=25 \%\right.$ Recommendation), and $75 \mathrm{~kg} \mathrm{KCl} \mathrm{ha}^{-1}$ and 100 kg SP-36 ha ${ }^{-1}$ (100\% recommendation) with increasing yield by 1.1 ton ha' ${ }^{-1}$ Harvested Dry Yield (GKP) and 1.03 t/ha Mill Dry Yield (GKG). If it was compared to fertilization based on farmer tradition, application of rice straw-titonia mix compost on intensification rice field could reduce commercial fertilizer by $50 \mathrm{~kg} \mathrm{Urea} \mathrm{ha}^{-1}(25 \% \mathrm{R})$, and $190 \mathrm{~kg} \mathrm{SP}^{-36} \mathrm{ha}^{-1}(95 \%)$.
\end{abstract}

Keywords: compost, fertilizers, intensification, rice straw, titonia.

\section{PENDAHULUAN}

Perlakuan pemupukan, terutama pupuk $P$ yang telah berlangsung lebih dari 30 tahun pada lahan sawah intensifikasi, telah menimbulkan akumulasi P. Hal ini disebabkan oleh pemupukan $P$ dengan dosis tinggi, dan sifat pupuk $P$ yang kurang larut dalam air, dan mudah diikat oleh komponen tanah. Dengan penambahan BO pada lahan sawah tersebut diharapkan akan dapat meningkatkan kelarutan $\mathbf{P}$ yang tertimbun dalam tanah.

Sumber bahan organik (BO) yang dapat dikembangkan insitu dan berkelanjutan di lahan persawahan adalah gulma (tumbuhan semak) Tithonia diversifolia atau titonia. Hakim dan Agustian (2003) menyatakan bahwa titonia mempunyai kandungan hara yang tinggi, yaitu 3,16 \% N, 0,38 \% P dan 3,45 \% $\mathrm{K}$. Selain hara $N$, $P$, dan $K$, titonia juga mempunyai kadar hara kalsium (Ca) 1,14 \%, magnesium (Mg) $0,78 \%$, ratio $\mathrm{C} / \mathrm{N}$ 13,96, kadar lignin 16,90 \%,dan selulosa 52,99\% (Gusnidar, 2007). Oleh karena itu, tumbuhan ini layak digunakan sebagai sumber hara, terutama $\mathbf{N}$ dan $\mathrm{K}$ bagi tanaman.

Jerami padi, berpotensi pula sebagai BO insitu di lahan persawahan. Namun, kadar haranya, terutama $\mathrm{N}$ sangat rendah, dan agak sukar lapuk. Jerami mengandung silikat (Si) 13,6\% (Susila, 1997), dan unsur Si jarang ditambahkan petani ke lahan persawahan. Apabila kedua jenis BO ini dicampur dalam pengomposannya apakah jerami dapat lebih cepat melapuk dan menyediakan unsur hara yang lebih banyak dibandingkan digunakan secara tunggal?. 
Bagaimanakah pengaruhnya terhadap hasil padi, pertu dipelajari dalam penelitian ini. Tujuan penelitian adalah untuk mempelajari pengaruh pemberian kompos titonia (Tithonia diversifolia) dan jerami dalam mengurangi penggunaan pupuk buatan dan hasil padi sawah intensifikasi.

\section{BAHAN DAN METODA}

Penelitian berbentuk Rancangan Acak Kelompok (RAK), dengan 6 perlakuan dan 3 kelompok. Perlakuan yang dicobakan adalah: $\mathbf{A}=$ Input pemupukan menurut tradisi petani ( $200 \mathrm{~kg}^{\text {Urea ha }}{ }^{-1}+200 \mathrm{~kg}$ SP$\left.36 \mathrm{ha}^{-1}\right), \mathbf{B}=$ Input rekomendasi $(\mathrm{R})(200 \mathrm{~kg}$ Urea ha $^{-1}+100$ kg SP-36 ha-1 +75 kg KCl ha $\left.^{-1}\right), \mathbf{C}=\operatorname{Kompos}\left(5\right.$ ton jerami ha' $\left.\mathbf{h}^{-1}\right)+\mathbf{R}$, $D=\operatorname{Kompos}\left(5\right.$ ton jerami ha $\left.\mathbf{h}^{-1}\right)+100 \% \mathrm{R}$, tanpa $\mathrm{KCl}+\mathrm{P}$-s, $\mathrm{E}=\mathrm{Kompos}(2,5$ ton titonia ha $\mathrm{ha}^{-1}+2,5$ ton jerami ha $\left.\mathrm{h}^{-1}\right)+$ Urea 75 \% R, tanpa KCl, dan P-s, F = Kompos (2,5 ton titonia $\mathrm{ha}^{-1}+2,5$ ton jerami ha' $\left.{ }^{-1}\right)+$ Urea $50 \%$ R, tanpa KCl, dan P-s.
Tanah sawah untuk penelitian mempunyai ciri seperti pada Tabel 1. Bahan yang dijadikan kompos dan hasil analisis kompos setelah 1 bulan ditampilkan pada Tabel 2.

Kompos tersebut diinkubasi selama 2 minggu sebelum tanam, diambil sampel tanah secara komposit setelah inkubasi, dianalisis sifat dan ciri kimianya. Penanaman bibit umur 12 hari, satu pertitik tanam (jarak 25cmx25cm). Pemupukan KCl dan Urea 1/3 dosis 2 Minggu Setelah Tanam (MST), dan Urea 2/3 bagian lagi diberikan umur 6 MST. Pemberian pupuk Urea, SP-36 dan KCl secara sebar, kecuali perlakuan pemupukan dengan P-s. Pengaturan air pada masa pertumbuhan vegetatif cukup lembab, kecuali digenangi selama tiga hari sebelum penyiangan. Pada 6 MST disemprot dengan Ripcord 5 EC (1 $\left.\mathrm{ccL}^{-1}\right)$, karena tanaman terserang ulat. Panen dilakukan setelah matang fisiologis.

Tabel 1. Hasil analisis sifat kimia tanah sawah intensifikasi Sicincin sebelum diberi perlakuan

\begin{tabular}{|c|c|c|}
\hline Jenis Analisis & Nilai & Kriteria \\
\hline Tekstur : & & Liat \\
\hline - $\quad$ Pasir \% & 41,86 & \\
\hline Debu \% & 11,63 & \\
\hline$-\quad$ Liat $\%$ & 46,51 & \\
\hline pH H $\mathrm{H}_{2} \mathrm{O}(1: 2)$ & 6,09 & Agak masam * \\
\hline $\mathrm{C}_{\mathrm{org}}(\%)$ & 6,27 & Tinggi $*$ \\
\hline N-total (\%) & 0,57 & Tinggi * \\
\hline Ratio C/N & 11,00 & Sedang ** \\
\hline P-tersedia (ppm) & 177,35 & Sangat tinggi * \\
\hline $\mathrm{Ca}_{\mathrm{dd}}\left(\operatorname{me}(100 \mathrm{~g})^{-1}\right.$ & 0,01 & Sangat rendah * \\
\hline $\operatorname{Mg}_{d d}\left(\operatorname{me}(100 \mathrm{~g})^{-1}\right.$ & 2,66 & Tinggi $*$ \\
\hline$K_{d d}\left(\operatorname{me}(100 g)^{-1}\right.$ & $\mathbf{0 , 5 8}$ & Sedang * \\
\hline KTK (me $(100 \mathrm{~g})^{-1}$ & 38,00 & Tinggi * \\
\hline $\mathrm{Cu}(\mathbf{p p m})$ & 14,37 & Sangat rendah $* * * *$ \\
\hline Zn (ppm) & 75,41 & Sedang $* * * *$ \\
\hline Si (ppm) & 60,12 & Kurang *** \\
\hline
\end{tabular}


Tabel 2. Kadar hara jerami dan titonia sebelum dan sesudah dikomposkan

\begin{tabular}{lcccc}
\hline Parameter & \multicolumn{2}{c}{ Sebelum dikompos } & & Kompos \\
\cline { 2 - 5 } Pengamatan & Tithonia & Jerami & Jerami & Jerami+Tithonia \\
\hline Kadar Air (\%) & $\mathbf{4 0 0}$ & $\mathbf{3 0 0}$ & $\mathbf{5 5 3 , 9 2}$ & $\mathbf{5 6 2 , 5 8}$ \\
Kadar hara : & & & & \\
N $_{\text {tot }}(\%)$ & $\mathbf{3 , 4 3}$ & $\mathbf{0 , 7 9}$ & $\mathbf{0 , 4 9}$ & $\mathbf{0 , 6 3}$ \\
P $_{\text {tot }}(\%)$ & $\mathbf{0 , 3 1}$ & $\mathbf{0 , 2 3}$ & $\mathbf{0 , 1 6}$ & $\mathbf{0 , 3 4}$ \\
K$_{\text {tot }}(\%)$ & $\mathbf{4 , 1 6}$ & $\mathbf{1 , 9 3}$ & $\mathbf{0 , 4 5}$ & $\mathbf{0 , 8 9}$ \\
Catot $_{\text {t\%) }}$ & $\mathbf{1 , 1 4}$ & $\mathbf{0 , 2 1}$ & $\mathbf{0 , 0 1}$ & $\mathbf{0 , 0 1}$ \\
Mg $_{\text {tot }}(\%)$ & $\mathbf{0 , 7 8}$ & $\mathbf{0 , 1 9}$ & $\mathbf{0 , 0 1}$ & $\mathbf{0 , 0 1}$ \\
$\mathbf{C}_{\text {tot }}(\%)$ & $\mathbf{4 7 , 8 9}$ & $\mathbf{4 4 , 9 5}$ & $\mathbf{3 3 , 3 5}$ & $\mathbf{3 9 , 1 8}$ \\
C/N & $\mathbf{1 3 , 9 6}$ & $\mathbf{5 6 , 9 0}$ & $\mathbf{6 8 , 0 6}$ & $\mathbf{6 2 , 1 9}$ \\
C/P & $\mathbf{1 5 4 , 4 8}$ & $\mathbf{1 9 5 , 4 3}$ & $\mathbf{2 0 5 , 8 7}$ & $\mathbf{1 1 6 , 9 6}$ \\
Warna & & & 7,5 YR $3 / 4$ & 7,5 YR 2/3 \\
& & & $($ coklat gelap) & (coklat sangat gelap) \\
\hline
\end{tabular}

\section{HASIL DAN PEMBAHASAN}

Nilai KTK, $K_{d d}$, Cadd, dan $\mathbf{M g}_{d d}$ setelah inkubasi dengan kompos

Aplikasi kompos $\mathbf{J}$ dan $\mathbf{J}+\mathbf{T}$ yang disertai PB meningkatkan KTK tanah. Nilai KTK, perlakuan kompos J + Urea $100 \% \mathrm{R}$ tanpa KCl + P-s (D) sebesar 55,27 me/100 g lebih tinggi dari perlakuan yang lainnya. Tingginya KTK perlakuan D disebabkan tingginya BO, yang mampu menjerap kation dalam dalam jumlah yang banyak. Nilai KTK pada pemberian kompos $\mathbf{J}+\mathbf{T}+$ Urea $75 \% \mathrm{R}$, tanpa $\mathrm{KCl}+\mathrm{P}$-s (E) dan perlakuan pemberian kompos $(\mathrm{J}+\mathrm{T})+$ Urea $50 \% \mathrm{R}$, tanpa KCl + P-s (F) yaitu 50,17 me/100 g dan 50,00 me/100 $g$ lebih rendah dibandingkan perlakuan $\mathrm{A}, \mathrm{B}$ dan $\mathrm{C}$. Namun, masih pada kriteria sangat tingggi (Tabel 3).

Daya jerap BO > koloid liat, berarti semakin tinggi kandungan BO suatu tanah semakin tinggi pula KTKnya (Hakim et al,
1986; Tan, 1998). Suryadi (1992) berpendapat bahwa peningkatan KTK tanah akibat pemberian kompos diduga karena meningkatnya muatan negatif dalam tanah, muatan negatif berasal dari gugus karboksil (COO - ) dan hidroksil (OH - ) yang dikandung kompos.

Nilai $K_{d d}$ tanah juga mengalami peningkatan dari tinggi (t) sampai sangat tinggi (st). Nilai $K_{d d}$ tanah sangat tinggi, diperoleh pada perlakuan kompos $\mathbf{J},(\mathbf{J}+\mathbf{T})$. Nilai $K_{d d}$ tertinggi diperoleh pada perlakuan D, yaitu 1,49 me $(100 \mathrm{~g})^{-1}$, diikuti oleh $F$ yaitu sebesar $1,46 \mathrm{me}(100 \mathrm{~g})^{-1}$ dan pada perlakuan tanpa kompos (A dan B) nilai $K_{\text {ddnya }}<1$ me $(100 g)^{-1}$. Berarti dengan pemberian kompos $\mathrm{J}$ dan $(\mathrm{J}+\mathrm{T})$ ini dapat meningkatkan ketersediaan $\mathrm{K}$ dalam tanah sehingga tersedia bagi tanaman. Di samping itu dengan pemberian kompos sebagai $\mathrm{BO}$ ke dalam tanah juga dapat melarutkan unsur $K$ yang terjerap, pada awalnya tidak tersedia menjadi tersedia bagi tanaman.

Tabel 3. Hasil pengukuran $\mathrm{KTK}, \mathrm{K}_{\mathrm{dd}}$, $\mathrm{Ca}_{\mathrm{dd}}$, dan $\mathrm{Mg}_{\mathrm{dd}}$ tanah sawah intensifikasi Sicincin sesudah inkubasi dengan kompos

\begin{tabular}{|c|c|c|c|c|}
\hline Perlakuan & KTK & $K_{d d}$ & $\mathbf{C a}_{d d}$ & $\mathbf{M g}_{\mathrm{dd}}$ \\
\hline & \multicolumn{4}{|c|}{.............................me/100 g........................... } \\
\hline A & 54,00 st & $\mathbf{0 , 8 3}{ }^{t}$ & $0,01^{\text {sr }}$ & $2,66^{t}$ \\
\hline B & 54,50 st & $0,93^{t}$ & 0,02 sr & $3,42^{t}$ \\
\hline C & 53,17 st & $1,17^{\mathrm{s}}$ & 0,02 sr & $4,01^{t}$ \\
\hline D & 55,27 st & $1,49^{\mathrm{s}}$ & $0,02^{\text {sr }}$ & $4,88^{t}$ \\
\hline $\mathbf{E}$ & 50,17 st & 1,09 s & $\mathbf{0 , 0 2}$ sr & $3,55^{t}$ \\
\hline $\mathbf{F}$ & $\mathbf{5 0 , 0 0}$ st & $1,46 \mathrm{~s}$ & $\mathbf{0 , 0 2}$ sr & $4,22^{t}$ \\
\hline
\end{tabular}

Keterangan : $\mathrm{sr}=$ sangat rendah, $r=$ rendah, $\mathrm{t}=$ tinggi, $\mathrm{st}=$ sangat tinggi 
Secara umum nilai $\mathbf{C a}_{d d}$ tanah sesudah inkubasi mengalami peningkatan dibandingkan dengan sebelum inkubasi, walaupun dalam kriteria sangat rendah (sr). Nilai Cadd akibat pemberian kompos $J$ dan $(\mathrm{J}+\mathrm{T})$ sebesar 0,02 me $(100 \mathrm{~g})^{-1}$ mengalami peningkatan dari pertakuan A. Berarti dengan penambahan kompos $\mathbf{J}$ dan $(\mathrm{J}+\mathrm{T})$ temyata juga memberikan pengaruh terhadap ketersediaan Ca dalam tanah meskipun hanya sedikit. Begitu juga dengan $\mathbf{M g}_{d d}$, walaupun masih tergolong kriteria tinggi (t), penambahan kompos $\mathrm{J}$ dan $(\mathrm{J}+\mathrm{T})$ temyata memberikan sumbangan $\mathrm{Mg}$ sehingga nilai $\mathrm{Mg}_{\mathrm{dd}}$ perlakuan $\mathrm{C}, \mathrm{D}, \mathrm{E}$ dan $\mathrm{F}$ meningkat dibandingkan perlakuan A dan B. Nilai $\mathrm{Mg}_{\mathrm{dd}}$ tertinggi diperoleh pada perlakuan $D(4,88 \mathrm{me} / 100 \mathrm{~g})$ dan yang terendah pada perlakuan A $\left(2,66 \mathrm{me}(100 \mathrm{~g})^{-}\right.$ 1) .

Nilai $\mathbf{C}_{\text {org, }} \mathbf{N}_{\text {tot }}$ dan Ratio C/N Tanah setelah inkubasi dengan kompos

Tabel 4, pemupukan menurut tradisi petani (A), input $R$ (B) dan pemberian kompos $J$ (C dan D) serta pemberian kompos (J+T) (E dan $F$ ) yang diiringi dengan pemberian $\mathrm{PB}$ temyata dapat meningkatkan kandungan $\mathrm{C}_{\text {org }}$ tanah sawah awal (6,76 \% kriteria tinggi). Nilai $\mathrm{C}_{\text {org }}$ tertinggi $9,90 \%$ diperoleh pada pemberian kompos $(\mathrm{J}+\mathrm{T})+$ Urea $75 \% \mathrm{R}$, tanpa $\mathrm{KCl}$ $+P-s(E)$ dan terendah pada input $R(B)$ yaitu $8,10 \%$.

Meningkatnya nilai $\mathrm{C}_{\text {org }}$ adalah akibat T mengandung $\mathrm{C}_{\text {tot }} 47,89 \%$. Titonia mudah lapuk $\left(\mathrm{C} / \mathrm{N}\right.$ rendah) sehingga $\mathrm{C}_{\mathrm{org}}$ tanah bertambah (Gusnidar, 2007). Penambahan PB dapat langsung menyediakan hara, diserap oleh tanaman sehingga ketersediaan hara tanaman terpenuhi. Oleh sebab itu, pada tanah dengan kadar $\mathrm{C} / \mathrm{N}$ sangat tinggi, sementara waktu pemberian $\mathrm{PB}$ dapat dikurangi sehingga dapat menghemat pengeluaran petani untuk membeli pupuk.

Pemberian kompos $\mathbf{J}$ dan $(\mathbf{J}+\mathbf{T})$ meningkatkan $\mathbf{N}$ tanah walaupun tidak terlalu tinggi. Nilai $\mathbf{N}_{\text {tot }}$ tertinggi $(0,74 \%)$ diperoleh pada perlakuan $D$, terendah 0,62 $\%$ pada perlakuan A. Suryadi (1992) mengemukakan bahwa $\mathbf{N}$ yang berasal dari BO melalui proses mineralisasi berubah menjadi $\mathbf{N}$ dalam bentuk tersedia, sehingga dapat meningkatkan $\mathbf{N}$ tanah. Kadar $\mathbf{N}$ tanah, mempengaruhi ratio $\mathrm{C} / \mathrm{N}$.

Tabel 5, nilai P-tersedia akibat pemberian BO masih dalam kriteria yang sama dengan tanah awal (kriteria sangat tinggi). Ketersediaan $\mathbf{P}$ dipengaruhi oleh $\mathbf{p H}$, BO, waktu, temperatur dan tipe liat. Meningkatnya P-tersedia akibat pemberian kompos sebagai sumber BO, selain karena kompos menyumbangkan $P$ pada tanah sawah, pemberian kompos juga dapat meningkatkan $\mathrm{pH}$ tanah sawah. Tingginya $P_{\text {ters }}$ juga diakibatkan oleh pemupukan $\mathbf{P}$ secara intensif setiap kali masa tanam dalam jangka waktu yang relatif lama, karena pada setiap kali masa panen akan meninggalkan residu $\mathbf{P}$ dalam tanah sawah. Penggenangan pada tanah sawah dapat pula meningkatkan ketersediaan P. Gusnidar (2007) mengemukakan bahwa penggenangan (6-12 minggu setelah pemberian T), ketersediaan $P$ semakin meningkat, sehingga peningkatan dosis $\mathrm{T}$ atau BO lain yang diberikan tidak terlihat pengaruhnya terhadap ketersediaan $P$.

Tabel 4. Hasil pengukuran $\mathrm{C}_{\text {org }}$, $\mathrm{N}$-total dan ratio $\mathrm{C} / \mathrm{N}$ tanah sawah intensifikasi Sicincin sesudah inkubasi dengan kompos

\begin{tabular}{|c|c|c|c|}
\hline Perlakuan & Corg $_{\text {org }}$ & $\mathbf{N}_{\text {tot }}$ & Ratio $\mathrm{C} / \mathrm{N}$ \\
\hline \multicolumn{4}{|c|}{................\%o.............. } \\
\hline $\mathbf{A}$ & 8,90 st & $0,62^{t}$ & $14,35^{\mathrm{s}}$ \\
\hline B & 8,10 st & $0,64^{t}$ & $12,66^{\mathrm{s}}$ \\
\hline C & 9,11 st & $0,64^{t}$ & $14,23^{s}$ \\
\hline D & 9,57 st $^{2}$ & $0,74^{t}$ & $14,28^{s}$ \\
\hline $\mathbf{E}$ & 9,90 st & $0,63^{t}$ & $17,30^{t}$ \\
\hline $\mathbf{F}$ & $\mathbf{9 , 3 2}$ st & $0,68^{t}$ & $13,71^{\mathrm{s}}$ \\
\hline
\end{tabular}

Keterangan : $\mathrm{s}=$ sedang, $\mathrm{t}=$ tinggi, $\mathrm{st}=$ sangat tinggi, $\mathrm{k}=$ kurang, $\mathrm{c}=$ cukup

Nilai P-tersedia, Si, Cu dan Zn Tanah setelah inkubasi dengan kompos 
Tabel 5. Hasil pengukuran P-ters, Si, Cu dan Zn tanah sawah intensifikasi Sicincin sesudah inkubasi dengan kompos

\begin{tabular}{|c|c|c|c|c|}
\hline Perlakuan & P-ters & $\mathbf{S i}$ & $\mathbf{C u}$ & $\mathbf{Z n}$ \\
\hline & \multicolumn{4}{|c|}{ 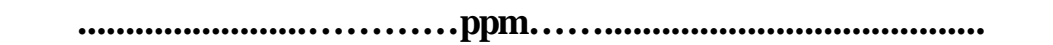 } \\
\hline $\mathbf{A}$ & 260,97 st & $60,12^{k}$ & $14,37^{r}$ & $75,41^{\mathrm{s}}$ \\
\hline B & $230,17^{\text {st }}$ & $65,05^{\mathrm{k}}$ & 11,39 sr & $\mathbf{5 8 , 3 3} \mathrm{s}$ \\
\hline C & 220,39 st & $109,93^{c}$ & 12,03 sr & $81,30^{\mathrm{s}}$ \\
\hline D & $268,80^{\text {st }}$ & $101,04^{\mathrm{c}}$ & $15,02^{r}$ & $43,46^{r}$ \\
\hline $\mathbf{E}$ & 274,74 st & $87,44^{\mathrm{c}}$ & $19,67^{r}$ & $67,37^{\mathrm{s}}$ \\
\hline $\mathbf{F}$ & 255,11 st & $\mathbf{7 4 , 7 7} \mathrm{c}$ & $20,51^{r}$ & $73,39 \mathrm{~s}$ \\
\hline
\end{tabular}

Keterangan : $\mathrm{sr}=$ sangat rendah, $\mathrm{r}=$ rendah, $\mathrm{s}=$ sedang, $\mathrm{st}=$ sangat tinggi, $\mathrm{k}=\mathrm{kurang}, \mathrm{c}=$ cukup

Kandungan Si tanah sesudah inkubasi kompos berkisar antara 74,77-109,93 ppm berada dalam kriteria cukup. Nilai tertinggi perlakuan $E \quad(109,93 \quad \mathrm{ppm})$ dan yang terendah pada perlakuan $A(60,12 \mathrm{ppm})$. Dari angka-angka tersebut nyatalah bahwa penggunaan BO dapat meningkatkan kadar hara tanah, dalam hal ini Si. Hara Si merupakan unsur essensial untuk tanaman padi-padian dan tidak penting untuk tanaman tertentu. Hampir semua tanaman mengandung Si dalam kadar yang berbedabeda dan sering menjadi sangat tinggi. Unsur Si dapat menaikkan produksi karena dapat memperbaiki sifat fisik tanaman dan berpengaruh terhadap kelarutan $P$ dalam tanah. Padi, misalnya memiliki kadar Si relatif tinggi dan melebihi unsur hara makro (N, P, K, Ca, Mg dan S). Apabila kadar $\mathrm{SiO}_{2}$ $<5 \%$, maka tegak tanaman tidak kuat dan mudah roboh. Oleh sebab itu perlu dilakukan pemberian $\mathrm{Si}$ misalnya melalui pemanfaatan jerami, agar tanaman dapat tegak dengan baik dan tidak mudah roboh. Pemberian Si dapat menyebabkan kenaikan ketersediaan $\mathrm{P}$, karena $\mathrm{Si}$ mampu menggantikan $P$ yang terentensi, sehingga $P$ yang tadinya tidak tersedia menjadi tersedia bagi tanaman. Hardjowigeno dan Rayes (2001) menyatakan bahwa, pada tanah sawah $\mathrm{Si}$ terlarut umumnya meningkat setelah penggenangan, karena : (a) pembebasan $\mathrm{Si}$ terjerap dalam oksihidroksida Fe dan $\mathrm{Al}$, (b) kenaikan pH akibat penggenangan dan (c) dekomposisi jerami padi yang kaya $S i$.

Nilai $\mathrm{Cu}$ dan $\mathrm{Zn}$ tanah sesudah inkubasi masih terdapat pada kriteria sangat rendah sampai sedang (11,39-81,30 ppm). Nilai $\mathrm{Cu}$ terendah pada input $\mathbf{R}$ dan pemberian kompos $\mathbf{J}+$ input $\mathbf{R}$, yaitu 11,39$12,03 \mathrm{ppm}$. Untuk perlakuan yang sama, nilai $\mathrm{Zn}$ mengalami peningkatan menjadi kriteria sedang $(58,33-81,30 \quad$ ppm). Selanjutnya untuk perlakuan $\mathrm{D}$, nilai Cu dan Zn terdapat pada kriteria rendah sedangkan pada perlakuan $\mathrm{E}$ dan $\mathrm{F}$ kadar $\mathrm{Cu}$ terdapat pada kriteria rendah dan $\mathrm{Zn}$ pada kriteria sedang.

Rendahnya kadar $\mathrm{Cu}$, disebabkan karena tingginya kadar $\mathrm{P}, \mathrm{N}$, dan $\mathrm{Zn}$ serta BO. Begitu pula dengan ketersediaan $\mathrm{Zn}$ dalam tanah yang juga dipengaruhi oleh $\mathrm{pH}$ tanah, kadar P, BO, dan penggenangan. Bila pH tanah tinggi, maka ketersediaan $\mathrm{Zn}$ menurun. Sebaliknya, bila pH tanah rendah, Zn tersedia meningkat. Kadar $\mathbf{P}$ dalam tanah mempengaruhi ketersediaan $\mathrm{Zn}$. Terjadinya reaksi ikatan antara $P$ dan $Z n$ begitu kuat akan menurunkan ketersediaan $\mathrm{Zn}$. Begitu juga dengan penambahan BO dan pemupukan yang tinggi sering diikuti munculnya gejala kekahatan $\mathrm{Zn}$. Hal ini disebabkan oleh adanya peningkatan kebutuhan Zn oleh mikrobia untuk pertumbuhannya, sehingga $\mathrm{Zn}$ menjadi kurang tersedia bagi tanaman. Selanjutnya penggenangan juga berpengaruh terhadap kelarutan Zn. Hal ini juga disebabkan karena terbentuknya $\mathrm{Zn}(\mathrm{OH})_{2}$ yang tidak larut sebagai akibat kenaikkan pH setelah penggenangan (Rosmarkam dan Yuwono, 2002). Lain halnya pada perlakuan kompos $(\mathrm{J}+\mathrm{T})$, kandungan $\mathrm{Cu}$ dan $\mathrm{Zn}$ nya sama-sama mengalami peningkatan.

Pengamatan terhadap tanaman

Tinggi tanaman (Tabel 6), tertinggi $(88,31 \mathrm{~cm})$ diperoleh pada perlakuan $\mathrm{C}$, diikuti oleh perlakuan $F(86,01 \mathrm{~cm})$ dan $E$ 
Tabel 6. Aplikasi kompos dan pupuk buatan terhadap tinggi tanaman, jumlah anakan total dan jumlah malai padi sawah intensifikasi Sicincin

\begin{tabular}{ccccc}
\hline Perdakuan & Tinggi tanaman & Anakan total & Jumlah malai & Bobot 1000 biji \\
\hline & $\mathbf{c m}$ & $\ldots \ldots \ldots \ldots$ buah.......... & g \\
A & $\mathbf{8 4 , 5 2}$ & 37,10 & $\mathbf{2 8 , 2 0}$ & 19,63 \\
B & $\mathbf{8 5 , 2 7}$ & 41,00 & 25,36 & 19,10 \\
C & $\mathbf{8 8 , 3 1}$ & 37,92 & 26,54 & 19,43 \\
D & $\mathbf{8 1 , 6 9}$ & 40,22 & 23,64 & 19,57 \\
E & $\mathbf{8 4 , 2 3}$ & $\mathbf{4 4 , 9 2}$ & $\mathbf{2 8 , 6 3}$ & $\mathbf{1 8 , 6 0}$ \\
F & $\mathbf{8 6 , 0 1}$ & $\mathbf{3 9 , 8 3}$ & $\mathbf{2 6 , 9 1}$ & $\mathbf{1 9 , 3 3}$ \\
\hline KK & $\mathbf{5 , 3 3 \%}$ & $\mathbf{5 , 9 5 \%}$ & $\mathbf{1 , 2 5} \%$ & $\mathbf{1 , 5 6 \%}$ \\
\hline
\end{tabular}

input $R(85,27 \mathrm{~cm})$ serta yang terendah terdapat pada perlakuan $\mathrm{D}(81,69 \mathrm{~cm})$. Pemberian kompos $J$ dan $T$ tidak berpengaruh nyata terhadap jumlah anakan total dan jumlah malai. Banyaknya jumlah anakan total dan jumlah malai pada perlakuan dibandingkan perlakuan A dan B disebabkan karena pemberian kompos $(\mathrm{J}+\mathrm{T})$ dapat menambah ketersediaan hara lebih banyak bila dibandingkan dengan $J$ yang dikomposkan. Hal ini disebabkan karena kadar hara $N$ meningkat sebesar $0,14 \%, P$ sebesar $0,17 \%$, dan $\mathrm{K}$ sebesar $0,44 \%$, sehingga pertumbuhan tanaman lebih baik..

Titonia adalah $\mathbf{P H}$ yang mengandung N dan K 2-4\% (Gusnidar, 2007; Gusnidar, Yasin dan Burbey, 2008) dan dibutuhkan oleh tanaman. Pemberian PH bertujuan untuk mengurangi pencucian (leaching) unsur hara, menambah kandungan BO, dan menambah $\mathbf{N}$ pada tanah (Hakim et al, 1986). Pengembalian $J$ ke dalam tanah dapat memperlambat berkurangnya $\mathrm{K}$ dan $\mathrm{Si}$ tanah. Di samping itu $J$ juga dapat meningkatkan kadar $\mathrm{C}_{\text {org }}, \mathrm{K}_{\mathrm{dd}}, \mathrm{Mg}_{\mathrm{dd}}$, KTK tanah, $\mathrm{Si}_{\text {ters }}$ dan meningkatkan stabilitas agregat tanah (Adiningsih, 1988).

Soepardi et al (1983), mengemukakan bahwa tanaman padi mempunyai perakaran yang lebat, sehingga akan memberikan tanggapan yang baik terhadap pupuk $P$ yang berada dekat perakarannya. Tanaman yang mempunyai perakaran yang baik akan mampu menyerap hara lebih baik. Selanjutnya Novita (2004) melaporkan bahwa serapan $P$ opleh tanaman akan merangsang pertumbuhan akar, sehingga volume dan panjang akar bertambah. Bertambahnya volume dan jauhnya jelajah akar yang berkontak dengan tanah akan meningkatkan serapan $\mathbf{P}$ dan pertumbuhan tanaman akan semakin baik.

Kompos $\mathbf{J}$ dan $(\mathbf{J}+\mathbf{T})$ dengan pengurangan $\mathrm{PB}$ dapat memberikan pengaruh relatif sama terhadap semua perlakuan. Produksi (Tabel 7), tertinggi diperoleh pada perdakuan $E\left(6,89\right.$ tonha $^{-1}$ GKG (8,07 ton GKP), diikuti perlakuan A $\left(6,41\right.$ tonha $^{-1}$ GKG $(7,25$ ton GKP), dan yang terendah pada perlakuan $F$ yaitu 5,30 tonha $^{-1}$ GKG (6,25 ton GKP). Kompos (J+T) dengan pengurangan dosis $\mathrm{PB}$, bobot gabah keringnya tidak jauh berbeda dengan perlakuan pemberian input pupuk menurut tradisi petani (A) dan input rekomendasi (B). Hal ini disebabkan kompos selain mengandung unsur hara (Tabel 2), juga $C / N$ masih cukup tinggi akan mendonong ketersediaan hara yang lebih baik dari sisa penguraian BO dan juga dapat meningkatkan ketersediaan $P$, sehingga pertumbuhan padi menjadi lebih baik dan hasil gabah meningkat (Suryadi, 1992).

Hasil penelitian menunjukkan bahwa kompos $(\mathbf{J}+\mathbf{T})$ pada sawah intensifikasi dapat mengurangi penggunaan PB sebanyak $50 \mathrm{~kg}$ Urea/ha (hemat $25 \% \mathrm{R}$ ) dan $75 \mathrm{~kg}$ $\mathrm{KCl} /$ ha (hemat $100 \% \mathrm{R}$ ), serta pemupukan $P$ cukup diberikan secara starter sebanyak 10 kg SP-36/ha (hemat $90 \% \mathrm{R}$ yaitu sebesar 90 kg SP-36/ha). Jika dibandingkan dengan dosis pemupukan yang biasa digunakan petani, maka pemberian kompos (J+T) dapat menghemat $25 \%$ Urea/ha (50 kg) dan $95 \%$ SP-36/ha (190 kg). Dengan demikian, hijauan $\mathbf{T}$ dan $\mathbf{J}$ dapat digunakan sebagai pupuk altematif yang dapat mengurangi penggunaan $\mathrm{PB}$. Pemberian kompos $(\mathrm{J}+\mathrm{T})$ $+75 \%$ Urea, tanpa KCl + P-s $10 \mathrm{~kg} \mathrm{SP-}$ $36 /$ ha merupakan perlakuan terbaik dengan 
Tabel 7. Aplikasi kompos dan pupuk buatan terhadap bobot gabah padi sawah intensifikasi Sicincin

\begin{tabular}{|c|c|c|c|c|c|c|}
\hline \multicolumn{2}{|c|}{ Bahan yang dikompos } & \multicolumn{3}{|c|}{ Pupuk Buatan } & \multicolumn{2}{|c|}{ Produksi } \\
\hline Jerami & Tithonia & Urea & SP-36 & KCl & GKP & GKG \\
\hline \multicolumn{2}{|c|}{....ton/ ha ${ }^{-1} \ldots$} & \multicolumn{3}{|c|}{.............kg ha ${ }^{-1} \ldots \ldots \ldots \ldots \ldots$} & \multicolumn{2}{|c|}{......ton hat ${ }^{-1} \ldots$} \\
\hline - & - & 200 & 200 & - & 7,25 & $6,41^{a}$ \\
\hline- & - & 200 & 100 & 75 & 6,97 & $5,86^{a}$ \\
\hline 5 & - & 200 & 100 & 75 & 7,12 & $6,05^{a}$ \\
\hline 5 & - & 200 & 10 & - & 7,17 & $6,28^{a}$ \\
\hline 2,5 & 2,5 & 150 & 10 & - & 8,07 & 6,89 a \\
\hline 2,5 & 2,5 & 100 & 10 & - & 6,25 & 5,30 a \\
\hline \multicolumn{2}{|c|}{ KK } & & & & \multicolumn{2}{|c|}{$1,59 \%$} \\
\hline
\end{tabular}

Keterangan : Angka-angka dalam kolom yang sama yang diikuti oleh huruf kecil yang sama adalah berbeda tidak nyata menurut uji BNT taraf $5 \%$

hasil GKP tertinggi sebesar 8,07 tonha ${ }^{-1}$ $\left(6,89\right.$ ton GKG ha' $\left.{ }^{-1}\right)$, yang diikuti oleh input pemupukan menurut tradisi petani (A) dengan hasil 7,25 tonha $^{-1}$ GKP $(6,41$ ton GKG ha-1). Jika dibandingkan dengan perlakuan $A$, maka perlakuan $\mathbf{E}$ dapat meningkatkan hasil GKP sebesar 0,82 tonha${ }^{1}\left(0,48\right.$ ton GKG ha' $\left.{ }^{-1}\right)$ dan bila dibandingkan dengan hasil GKP pada input rekomendasi umum (B) yaitu sebesar 6,97 tonha-1 $(5,86$ ton GKG ha' ${ }^{-1}$, maka perlakuan $\mathbf{E}$ dapat meningkatkan hasil GKP sebesar 1,1 ton GKP ha' ${ }^{-1}$ (1,03 ton GKG ha'). Berdasarkan kenaikan hasil yang diperoleh, berarti pemberian kompos jerami campur titonia dapat meningkatkan produksi sekitar 1,1 ton GKP ha' ${ }^{-1}(1,03$ ton GKG ha-1).

\section{KESIMPULAN DAN SARAN}

Berdasarkan hasil penelitian yang telah diuraikan maka dapat ditarik kesimpulan sebagai berikut :

1. Aplikasi kompos jerami campur titonia pada sawah intensifikasi dapat mengurangi penggunaan pupuk buatan sebanyak $50 \mathrm{~kg}^{\text {Ureaha }}{ }^{-1}$ (hemat $25 \% \mathrm{R}$ ) dan $75 \mathrm{~kg} \mathrm{KCl} \mathrm{ha}^{-1}$ (hemat $100 \% \mathrm{R}$ ), serta SP-36 sebesar $90 \mathrm{~kg} / \mathrm{ha}(90 \% \mathrm{R})$.

2. Aplikasi kompos jerami campur titonia + $75 \%$ Urea R, tanpa KCl + P-strater 10 kg SP-36/ha (E) merupakan perlakuan terbaik dengan hasil gabah kering panen (GKP) tertinggi sebesar 8,07 ton ha $^{-1}$ $\left(6,89\right.$ ton GKG ha' $\left.{ }^{-1}\right)$, yang diikuti oleh input pemupukan menurut tradisi petani (A) dengan hasil GKP sebesar 7,25 ton ha $^{-1}\left(6,41\right.$ ton GKGha' $\left.{ }^{-1}\right)$. Jika dibanding dengan perlakuan input pemupukan menurut tradisi petani $(200 \mathrm{~kg}$ Urea/ha + $200 \mathrm{~kg} \mathrm{SP-36/ha),} \mathrm{maka} \mathrm{perlakuan} \mathrm{E}$ dapat meningkatkan hasil GKP sebesar 0,82 ton ha $^{-1}\left(0,48\right.$ ton GKG ha $\left.{ }^{-1}\right)$ dan dengan input rekomendasi umum hasil GKP sebesar 6,97 ton ha $^{-1}(5,86$ ton GKG ha' ${ }^{-1}$ ), maka perlakuan $\mathbf{E}$ dapat meningkatkan hasil GKP sebesar 1,1 ton GKP ha' $(1,03$ ton GKG ha' $)$.

Aplikasi kompos jerami campur titonia sebagai sumber bahan organik untuk mengurangi penggunaan pupuk Urea, SP-36 dan $\mathrm{KCl}$ dapat disarankan karena dapat menghemat pemakaian pupuk buatan dan meningkatkan hasil padi.

Ucapan Terima Kasih

Pada kesempatan ini penulis menyampaikan ucapan terima kasih kepada Badan Penelitian dan Pengembangan Pertanian (Litbang) Pertanian yang telah mendanai penelitian ini.

\section{DAFTAR PUSTAKA}

Adiningsih, S., dan Rochayati, S. 1988. Peranan Bahan Organik Dalam Meningkatkan Efisiensi Penggunaan Pupuk dan Produksi Tanah. hlm.dalam Prosiding Lokakarya 
Nasional Penggunaan Pupuk, Cipayung, 16-17 November 1986. Pusat Penelitian Tanah dan Agroklimat, Bogor.

Gusnidar. 2007. Budidaya dan Pemanfaatan Tithonia diversifolia untuk Menghemat Pemupukan N, P, dan K Padi Sawah Intensifikasi [Disertasi]. Padang. Doktor Program Pascasarjana UNAND. 256 hal.

Gusnidar, S.Yasin dan Burbey. 2008. Pemanfaatan Gulma Tithonia diversifolia dan Jerami Sebagai Bahan Organik In Situ Untuk Mengurangi Penggunaan Pupuk Buatan serta Meningkatkan Hasil Padi Sawah Intensifikasi. Laporan Hasil Penelitian. Universitas Andalas. Padang. 49 halaman.

Hakim, N., Nyakpa, M.Y., Lubis, A.M., Nugroho, G., Saul, M.A., Diha, M., Hong, GB., Bailey, H.H. 1986. Dasardasar Ilmu Tanah. Penerbit Universitas Lampung. Lampung. 488 hal.

Hakim, N., dan Agustian. 2003. Gulma Tithonia dan Pemanfaatannya sebagai Sumber Bahan Organik dan Unsur Hara Untuk tanaman Hortikultura. Laporan Penelitian Hibah Bersaing XI/I Perguruan Tinggi Fakultas Pertanian Universitas Andalas Padang. Hardjowigeno, S., dan Rayes, M.L. 2001. Tanah Sawah. IPB. Bogor. 154 hal.

Hardjowigeno, S. 2003. Ilmu Tanah. Akademika Pressindo. Jakarta. 286 hal.

Novita, S. 2004. Pengaruh Pemberian $P$ Starter Terhadap Hasil Padi (O ryza sativa L) Pada Daerah Intensifikasi Sumani Kecamatan X Koto Singkarak Kabupaten Solok [Skripsi]. Padang. Fakultas Pertanian Universitas Andalas. 62 hal.

Rosmarkam, A., dan N, W. Yuwono. 2002. Ilmu Kesuburan Tanah. Kanisius. Yogyakarta. 224 hal.

Soepardi, G. 1983. Sifat dan Ciri Tanah. Fakultas Pertanian Bogor. Bogor. 866 hal.

Suryadi. 1992. Pengaruh Pemberian Kompos dan Pupuk TSP terhadap Ketersediaan Fosfat dan Produksi
Padi Sawah [Skripsi]. Padang. Fakultas Pertanian universitas Andalas.

Susila, P. 1997. Kandungan Asam Humat selama Pengomposan Jerami Padi (O ryza sativa. L) dan Alang-Alang (Imperata cylindrica .L) dengan Menggunakan EM$_{4}$ [Skripsi]. Padang. Fakultas Pertanian Universitas Andalas. 77 hal.

Tan, KH. 1998. Dasar-dasar Kimia Tanah (terjemahan). Gadjah Mada University Press. 295 halaman.

Team 4 Architechs and consulting Engineers, bekerjasama dengan Fakultas Pertanian Universitas Andalas. 1983. Survey tanah dan kesesuaian lahan Balai Penelitian Tanaman Pangan Sukarami. Fakultas Pertanian Universitas Andalas. 101 halaman. 